\title{
The prospects of use of silicon photodiodes for registration alpha, beta radiation and neutrons
}

\author{
E.F.Voronkin, B.V.Grinyov \\ Institute for Scintillation Materials, STC "Institute for Single Crystals", \\ National Academy of Sciences of Ukraine, \\ 60 Nauky Ave., 61001 Kharkiv, Ukraine
}

Received March 17, 2016

The purpose of the current work is an investigation of possibility of use of silicon photodiodes for registration alpha, beta radiations and neutrons. Electronic physical properties of the photodiodes which provide spectrometer characteristics of semiconductor detectors of nuclear radiations, such as: electronic noise, thickness of a sensitive layer, thickness of a surface not sensitive layer, are analyzed. It is shown that power permission for alpha particles is equal to $10-25 \mathrm{keV}$ that which corresponds to resolution of the best surface-barrier semiconductor detectors. Also photodiodes can be used for measurement of a stream of beta particles, in spectrometry till energy value of $300 \mathrm{keV}$ and for measurement of streams thermal and the fast neutrons with efficiency of about $1 \%$. Operational characteristics of the photodiodes allow use them in industrial platforms of nuclear objects and in the field conditions.

Keywords: silicon photodiodes, power permission, thermal and the fast neutrons.

Исследована возможность применения кремниевых фотодиодов для регистрации альфа-, бета-излучения и нейтронов. Проанализированы электронно-физические свойства фотодиодов, которые обеспечивают спектрометрические характеристики полупроводниковых детекторов ядерных излучений, такие как: электронные шумы, толщина чувствительного слоя, толщина поверхностного нечувствительного слоя. Показано, что энергетическое разрешение для альфа-частиц равно $10-25$ кэВ, что соответствует разрешению лучших поверхностно-барьерных полупроводниковых детекторов. Также фотодиоды могут быть использованы для измерения потока бета-частиц, в спектрометрии до энергии 300 кэВ и для измерения потоков тепловых и быстрых нейтронов с эффективностью около 1 \%. Эксплуатационные характеристики фотодиодов допускают использование их на промышленных площадках ядерных объектов и в полевых условиях.

Перспективи застосування кремнієвих фотодіодів для ресстрації альфа-, бета-

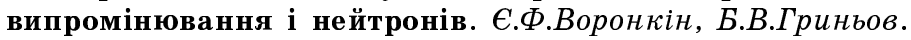

Вивченно можливості застосування кремнієвих фотодіодів для реєстрації альфа-, бета-випромінювань та нейтронів. Проаналізовано електронно-фізичні властивості фотодіодів, які забезпечують спектрометричні характеристики напівпровідникового детектора ядерних випромінювань, як то: електронні шуми, товщина чутливого шару, товщина поверхневого нечутливого шару. Показано, що енергетичний дозвіл для альфачастинок дорівнюе 10-25 кеВ, що порівняно 3 дозволом у кращих поверхнево-бар'єрних напівпровідникових детекторів. Також фотодіоди можуть бути застосовані для вимірювання потоку бета-частинок, в спектрометрії до енергії 300 кеВ та для вимірювання потоку теплових i швидких нейтронів 3 ефективністю близько $1 \%$. Експлуатаційні характеристики фотодіодів допускають застосовувати їх на промислових площадках ядерних об'єктів та у польових умовах. 


\section{Introduction}

At the moment, there is a wide range of instruments for radiation contamination measurement (DP-5V, IMD-1, IMD-12, IMD21, MKS-U and MKS-0.5. etc.).

These instruments put forward a number of requirements:

- measurement of the exposure dose of $10 \mathrm{mR} / \mathrm{h}$ to $103 \mathrm{R} / \mathrm{h}$;

- registration of gamma rays in the energy range from $10 \mathrm{keV}$ to $3 \mathrm{MeV}$;

- measurement of the flux density of $\alpha-, \beta$-radiation;

- automatic transfer of intelligence information to the collecting and processing information point (IMD-31).

Analysis of available dosimetry instruments indicates that for today it does not exist the universal instruments that provide measurement of the above characteristics at the same time with one device and the registration of neutron radiation at nuclear facilities, customs checkpoints and radiation survey.

Industry produces surface-barrier silicon detectors for alpha spectrometry having the area from 0.1 to $4 \mathrm{~cm}^{2}$.

The best samples have a resolution of energy on the line of plutonium-238 - 10$12 \mathrm{keV}$.

It is interesting to investigate characteristics of silicon photodiodes FD337A [1] as they have the following useful properties:

* The open surface of p-n junction area is $1 \mathrm{~cm}^{2}$.

* Manufacturing technology of p-n junction is diffusion of boron, which allows counting the increased radiation resistance [2].

* The thickness of the p-n junction can reach $0.3 \mathrm{~mm}$, allowing measurements of the energy of beta-particles up to $300 \mathrm{keV}$, and alpha-particles up to $10 \mathrm{MeV}$.

* It is characterized by the several times smaller price due to large-scale domestic production.

Sufficiently high energy resolution can be obtained when a value of the p-n junction have a large resistance, so the photodiodes were initially chosen according to the maximum resistance of the total consignment.

Evaluation of the threshold of resistance $\sigma_{n}$ was carried out as follows: the standard deviation of average current noise is estimated as:

$$
\sigma_{n}=\sqrt{\frac{U t}{R e}},
$$

where $U-$ shift on detector; $t$ - time of drift of carriers between electrodes; $R-$ detector resistance; $e-$ electron charge.

As the analytical resolution of superficial and barrier detectors reaches 0.1$0.3 \%$ when energy of alpha particles is $1-$ $2 \mathrm{MeV}$, we set a boundary ratio signalnoise, equal $10^{-3}$, then $\sigma_{n} W / E=10^{-3}$, where $W$ - energy of formation of electron-hole pairs, eV; $E$ - energy of an alpha particle, $\mathrm{MeV}$, and we get a ratio for detector resistance

$$
R \geq\left(\frac{W}{E}\right)^{2} \frac{U t}{e} \cdot 10^{6} .
$$

Using tabular values of mobility and time of life of carriers for silicon the boundary resistance of the detector was estimated in the order of magnitude of $10^{9} \mathrm{Ohm}$.

Further the detectors, which are selected by value of sufficiently large resistance $\left(6 \cdot 10^{8}-7 \cdot 10^{9} \mathrm{Ohm}\right)$ were placed in the vacuum chamber with an alpha source from the set of OSAI of plutonium-238, wherein: the source thickness equivalent $\left(d_{\text {sou }}\right)$ equaled $8 \mathrm{keV}$, angular collimation of the source added to an equivalent of thickness additionally $2 \mathrm{keV}\left(d_{\text {coll }}\right)$.

For strengthening of the detector signal the preamplifier with an equivalent of noises $7 \mathrm{keV}$ was used.

In Figure it is presented the energy spectrum of alpha particles from the plutonium source where the half-width of peak is $16 \mathrm{keV}$. Substituting in formula (3) values of noise characteristics of the preamplifier and thickness of the source, we get permission of the detector for the researching samples $\Delta E_{\text {det }}$

$$
\Delta E_{\mathrm{det}}=\sqrt{\Delta E_{\exp }^{2}-\left(d_{\text {sou }}+d_{\text {coll }}\right)^{2}}
$$

equal to $10-25 \mathrm{keV}$, which is comparable to the characteristics of serially produced surface barrier detectors.

The high value of the detectors energy resolution, in particular, shows the small thickness of the surface layer, which is insensitive to alpha radiation. The thickness of the surface layer was measured under irradiation of the detector by the protons flow and helium ions from the accelerator in the energy range of $20-300 \mathrm{keV}$. It is seen that $100 \%$ registration of protons was 


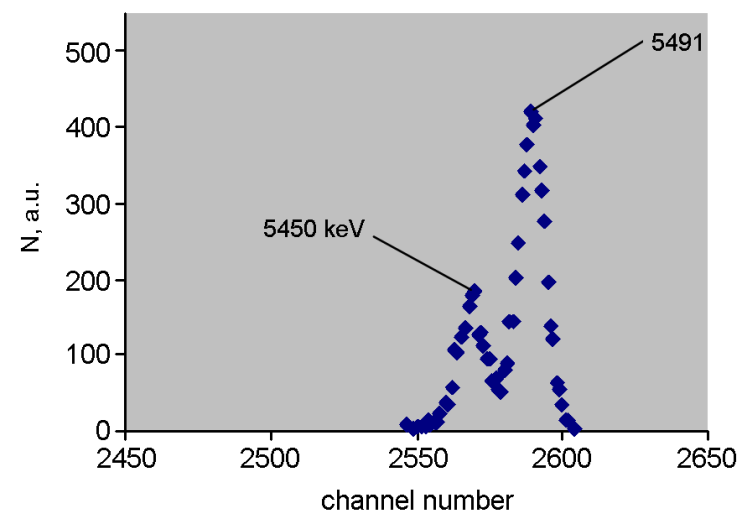

Fig. 1. Energy spectrum of alpha particles of plutonium-238.

carried out with excess energy more than $35 \mathrm{keV}$, and registration of helium at the energy of more than $65 \mathrm{keV}$. Considering the energy loss in silicon, the thickness of the insensitive layer was estimated with an accuracy of $20 \%$ and ranged from 0.16 to $0.19 \mu \mathrm{m}$ for different detectors. Therefore, it seems interesting to use the detector for registration of beta particles of low energy, in particular for the determination of tritium. Experiments were carried out at the registration in counter mode beta radiation from the tritium source and it was determined that the detection efficiency reaches $30 \%$.

The effective thickness of the detector was measured by registration of beta particles from the source of cobalt- 60 from a set of OSGI. It was found that the range of electrons fully consistent in the working thickness of the detector. This allows us to use the detectors for beta-particle spectrometry with the boundary energy of $300 \mathrm{keV}$. Also, experiments for recording of fast and thermal neutrons were conducted. Fast neutrons were detected by nucleus return of hydrogen from the polyethylene coating on the surface of the detector, and the thermal neutrons were recorded using the converters from boron. The efficiency of detection in the both cases was about $1 \%$, wherein the gamma-ray background exceeded the level of neutron flow in $10^{3}$ times. Because it is important to measure the flow of neutrons, beta-particles, alpha-particles in strong gamma fields it was investigated the radiation resistance of the detectors. The investigation was carried out on a by linear electron accelerator with the boundary energy of braking gamma-radiation of $10 \mathrm{MeV}$ to the exposure dose of $10^{6} \mathrm{rad}$.

After irradiation of gamma rays the spectrometric characteristics of the detectors were investigated. It was revealed that the signal amplitude decreased by $20 \%$. But it almost can be restored by increasing bias voltage from 20 to $50 \mathrm{~V}$. The energy resolution of the detector is deteriorated from 15 to $45 \mathrm{keV}$.

\section{Conclusions}

FD337A photo diodes can be used as detectors of nuclear radiations (alpha, beta, and neutron) at the considerable gamma background that does them to be attractive for application in industrial platforms of nuclear objects and in the field conditions. As the diodes are insensitive to gamma radiation, measurement of gamma streams is effective by telluride - cadmium detectors [3].

\section{References}

1. Y.F.Voronkin, A.N.Grigoryev, Functional Materials, 21, 352 (2014).

2. A.Kazanskiy, Yu.A.Matusevich, Basics of Experimental Methods of Nuclear Physics, Atomizdat, Moscow (1970) [in Russian].

3. N.E.Polyanskiy, A.N.Grigorev, A.G.Kareev, T.A.Zhadan, Vestnik Kharkovskogo Universiteta, No.10 , 153 (2002). 